\title{
Debit Cards Payment Behaviour of Consumers at Bhat-Bhateni Supermarket and Department Store in Kathmandu
}

\author{
Shrishna Karanjit ${ }^{11}$
}

\begin{abstract}
This paper attempts to identify thedifferent factors affecting consumers on adoption of debit cards with reference to Bhat-Bhateni Supermarket and Department Store (BSDS) in Kathmandu Valley. A month long survey was conducted amongtheconsumers of Kathmandu, who shopped at BSDS in which 175 respondents were interviewed using convenient sampling. For the purpose of study, two models were devised considering both debit card users and nondebit card users. The study showed higher preference and interest among the consumers in using debit cards than cash while making payments. The results also showed that the debit payment behavior among customers varied across nationality and income. Further, it revealed that themost significant factors influencing the debit payment behavior were perceived ease of use and usefulness of the card among others.
\end{abstract}

Key words: debit card payment behaviour, descriptive statistics and primary survey

\section{Introduction}

It was Nabil Bank Limited that introduced credit card in Nepal for the first time in early 1990 A.D. Likewise, Himalayan Bank Ltd introduced the first Automated Teller Machine (ATM) in 1995 A.D. From then to now electronic payment through debit cards has evolved tremendously and has obtained vast popularity in Nepal,especially among the urban dwellers. Thus, an understanding of changes in the debit payment behavior of consumers can help the marketers provide value added services to their consumers.

There is an urgent need for a research to understand theconsumer behavior relating to the use of debit cardsin under-developed countries like Nepal. As per the researcher's knowledge no previous studies have been conducted in any Departmental Stores of Nepal to figure out varied characteristics of such users on purchasing points. This study was conducted to determine the most significant

1 Ms. Karanjit is working as Business Analyst at Jagdamba Foods Pvt. Ltd.

Corresponding email:shrishna@gmail.com 
elements affecting the debit payment behavior of consumers representing Kathmandu Valley and it attempted to validate relationship between them. It is believed that the present study will be a benchmark model to understand the basic demographic characteristics of these consumers of Supermarket and Departmental Stores.

\section{Literature Review}

Many studies have been conducted worldwide to analyze consumer's use of debit cards at point-of-sales. Debit card alongside credit and prepaid card payments are substituting cash at major purchasing points in developed countries. A study in the U.S. by Javeline Strategy and Research (2012) found that debit and credit cards overtook cash for bulk of sales volume at retail points-of-sale in the U.S. This is supported by previous studies in the U.S. by Meijer, Schuh and Zabek (2011), which concluded that debit cards were the most commonly used payment instrument, especially among young consumers.

Another study from Borzekowski, Kiser, \& Ahmed (2006) showed that debit card was used specifically as a substitute of cash and check which cited convenience as themajor factor to influence debit card use at Point-of-Sales in the U.S. A study in Thailand obtained similar results which stated that consumers in Songkhla Province of Thailand used debit cards mostly for spending rather than withdrawing cash, and the users were mostly between the ages of 21-30. Noknoi, Ngowsiri, \&Boripunt (2009) also revealed that consumer behavior was dependent on demographic characteristics, especially on occupation, income and marital status. Bhatta (2010) provided only aglimpse of consumers' use of debit cards in Kathmandu, which concluded that more consumers used the cards for cash withdrawal than for shopping.However, a comprehensive study on consumers' payment behavior through debit cards has not been done in Nepalese context.

\section{Methodology}

The study is both qualitative and quantitative in nature, which is more of exploratory ratherthan truly a nationally representative survey. The research started by exploring the present context of debit card use at ATM counters and at point-ofsales. Later, to understand consumer's perception towards debit card use, quantitative research technique i.e. a structured questionnaire was used. The study represents the consumers of Kathmandu Valley - the capital and central hub for modern amenities and facilities in the country. The survey was conducted among randomly selected 175 customers of Bhat-Bhateni Supermarket and Department Store in Kathmandu during a period of one-month. The departmental store is chosen, since, it is the leading departmental chain with highest number of store chains and largest customer base than any other departmental stores in Nepal, that 
claims to have 42,000 customers in one day. For purpose of this study, on an average, everyday 6 respondents were selected to fill the questionnaire and only those shoppers who possessed at least one debit card were chosen for the survey.

Both primary and secondary sources of data were used for the study. As a primary source of data, quantitative method like researcher administered questionnaire was used, in the meantime, qualitative method like observation, face to face interview with the representatives of Bhat-Bhateni, and other stores along with card issuers was done. Researcher administered questionnaire technique was chosen to minimize the non-sampling errors, like response errors and non-response bias to some extent. For secondary source, several articles, journals relating to electronic payments and consumer behaviour were referred.

The study extends the basic model into two different sections to look into perspective from both debit and non-debit users at the point-of-sales. It tries to overlap the gap that existed in Nepalese market for the requirement of a study on consumer's debit payment behavior. The conceptual framework of the model has been developed as follows;

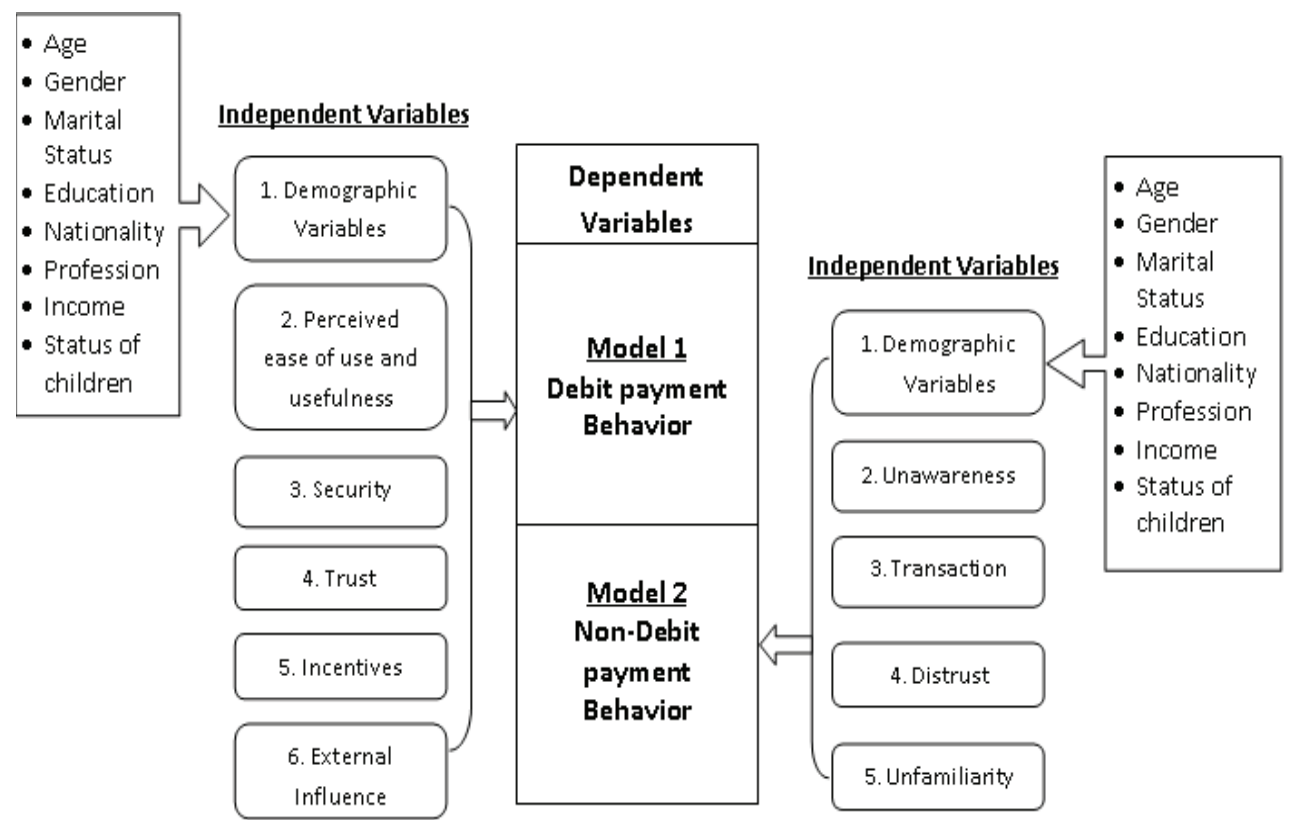

Figure 1: Conceptual Framework 
The above figure shows the framework of the study. First model aims to evaluate debit payment behavior whereas, second model attempts to evaluate non-debit payment behavior among the debit card users. Different questions were categorized under the identified factors to evaluate both the models, as follows:

Influential factors for the debit payment behaviour of consumers in model- 1 were classified as: Demographic characteristics, Perceived Ease of use and Usefulness (PEU), Security, Trust, Incentives on debit use, and External influence. Under Demographic Variables, consumers were categorized under nationality, gender, marital status, age, education, profession, income and status of children. Least square regression equation is used for validating relationship for estimating average response value, which is developed as shown below:

$$
\mathrm{Y}=\mathrm{b}_{0}+\mathrm{b}_{1} \chi_{1}+\mathrm{b}_{2} \chi_{2}+\mathrm{b}_{3} \chi_{3}+\mathrm{b}_{4} \chi_{4}+\mathrm{b}_{5} \chi_{5}+\mathrm{e}
$$

Where, $\mathrm{Y}=$ Debit payment behaviour, $\mathrm{b}_{0}=$ Constant, $\chi_{1}=$ Perceived Ease of use and usefulness $\chi_{2}=$ Security, $\chi_{3}=$ Trust, $\chi_{4}=$ Incentives, $\chi_{5}=$ External influences, and $\mathrm{e}=$ Disturbance term

In model 2, the influential factors identified to evaluate the non-debit payment behavior are: Demographic Characteristics, Unawareness, Transaction Fee, Distrust and Unfamiliar Demographic variables are categorized as in model-1. To determine the relationship, least square regression equation for estimating average response value is developed as:

$$
\mathrm{Z}=\alpha_{0}+\alpha_{1} \mathrm{y}_{1}+\alpha_{2} \mathrm{y}_{2}+\alpha_{3} \mathrm{y}_{3}+\alpha_{4} \mathrm{y}_{4}+\mathrm{e}
$$

Where, $\mathrm{Z}=$ Non- Debit payment behaviour, $\alpha_{0}=$ Constant, $\mathrm{y}_{1}=$ Unawareness, $\mathrm{y}_{2}=$ Transaction Fee, $\mathrm{y}_{3}=$ Distrust, $\mathrm{y}_{4}=$ Unfamiliarity and $\mathrm{e}=$ Disturbance term

\section{Data Analysis}

The demographic distribution of respondents along with the results from the entire survey is shown in the following table: 
Table. 1: Crosstab between demographic variables and users, non-users of debit cards at POS

\begin{tabular}{|c|c|c|c|}
\hline & $\begin{array}{l}\text { Users of debit } \\
\text { cards at POS }\end{array}$ & $\begin{array}{l}\text { Non-users of debit } \\
\text { cards at POS }\end{array}$ & Total \\
\hline $\begin{array}{l}\text { Gender } \\
\text { Male } \\
\text { Female }\end{array}$ & $\begin{array}{l}58(58.6) \\
46(60.5)\end{array}$ & $\begin{array}{l}41(41.4) \\
30(39.5)\end{array}$ & $\begin{array}{l}99(100.0) \\
76(100.0)\end{array}$ \\
\hline $\begin{array}{l}\text { Marital Status } \\
\text { Married } \\
\text { Single } \\
\end{array}$ & $\begin{array}{l}49(65.30) \\
55(55.0)\end{array}$ & $\begin{array}{l}26(37.70) \\
45(45.0)\end{array}$ & $\begin{array}{l}75(100.0) \\
100(100.0)\end{array}$ \\
\hline $\begin{array}{l}\text { Age } \\
<18 \text { yrs } \\
19-25 \mathrm{yrs} \\
26-35 \mathrm{yrs} \\
36-50 \mathrm{yrs} \\
>51 \mathrm{yrs} \\
\end{array}$ & $\begin{array}{l}1(25.0) \\
28(58.3) \\
51(56.0) \\
20(90.9) \\
4(40.0)\end{array}$ & $\begin{array}{l}3(75.0) \\
20(41.7) \\
40(44.0) \\
2(9.1) \\
6(60.0) \\
\end{array}$ & $\begin{array}{l}4(100.0) \\
48(100.0) \\
91(100.0) \\
22(100.0) \\
10(100.0) \\
\end{array}$ \\
\hline $\begin{array}{l}\text { Profession } \\
\text { Business } \\
\text { Student } \\
\text { Service } \\
\text { Job } \\
\text { Others }\end{array}$ & $\begin{array}{l}13(56.5) \\
29(63.0) \\
13(43.3) \\
44(68.8) \\
5(41.7)\end{array}$ & $\begin{array}{l}10(43.5) \\
17(37.0) \\
17(56.7) \\
20(31.2) \\
7(58.3)\end{array}$ & $\begin{array}{l}23(100.0) \\
46(100.0) \\
30(100.0) \\
64(100.0) \\
12(100.0)\end{array}$ \\
\hline $\begin{array}{l}\text { Education } \\
\text { Primary } \\
\text { Secondary } \\
\text { Higher Secondary } \\
\text { Bachelors } \\
\text { Masters and above }\end{array}$ & $\begin{array}{l}4(100.0) \\
3(50.0) \\
0(0.0) \\
29(50.9) \\
68(64.2)\end{array}$ & $\begin{array}{l}0(0.0) \\
3(50.0) \\
2(100.0) \\
28(49.1) \\
38(35.8)\end{array}$ & $\begin{array}{l}4(100.0) \\
6(100.0) \\
2(100.0) \\
57(100.0) \\
106(100.0) \\
\end{array}$ \\
\hline $\begin{array}{l}\text { Income } \\
<15000 \\
15000-30000 \\
31000-50000 \\
\text { Above } 51000 \\
\end{array}$ & $\begin{array}{l}31(57.4) \\
30(55.6) \\
19(57.6) \\
24(70.6)\end{array}$ & $\begin{array}{l}23(42.6) \\
24(44.4) \\
14(42.4) \\
10(29.4) \\
\end{array}$ & $\begin{array}{ll}54 & (100.0) \\
54 & (100.0) \\
33 & (100.0) \\
34 & (100.0) \\
\end{array}$ \\
\hline Total & $104(59.4)$ & $71(40.6)$ & 175(100.0) \\
\hline $\begin{array}{l}\text { Status of Children } \\
\text { No children } \\
1 \text { or more children }\end{array}$ & $\begin{array}{l}27(64.3) \\
22(66.7) \\
\end{array}$ & $\begin{array}{l}15(35.7) \\
11(33.3) \\
\end{array}$ & $\begin{array}{l}42(100.0) \\
33(100.0) \\
\end{array}$ \\
\hline Total & $49(65.3)$ & $26(34.7)$ & $75(100.0)$ \\
\hline
\end{tabular}

Results show that most of the customers of Bhat-Bhateni i.e. 104 (59.4\%), use debit cards for purchasing while $71(40.6 \%)$ did not use the cards for purchasing.Across gender, more female $(60.5 \%)$ use debit cards at point-of-sales (POS) and $41.4 \%$ male did not use card for purchasing. Likewise, across marital status, there were more married respondents $(65.30 \%)$; across age group, more 
respondents whose age range was between 36-55 years of age (90.9\%); across profession, job holders (68.8\%); under income category, those earning above NRs. 51,000 salary (70.6\%); and across the status of children, there were more respondents to use debit cards at point-of-sales who had one or more children $(66.7 \%)$.

Most of the debit card users' preferred Visa Electron debit card (86) for payment followed by SCT (24). Most of the consumers had already used the card at POS for more than a year $(52.9 \%)$ and most of them use the cards in department stores like Saleways, BigMart, Namaste, and Bluebird among others besides Bhat-Bhateni. Other than departmental stores most of the respondents use the cards for payment at clothing stores (62), followed by restaurants (57). The respondents frequently visitBhat-Bhateni for purchase, but their percentage of using debit cards for payments at Bhat-Bhateni was low. Only $25 \%$ of them used the card frequently at Bhat-Bhateni. Similarly, most of consumers $(70 \%)$ did not face problems while using the card at Bhat-Bhateni. Those who faced problems at Bhat-Bhateni mentioned acceptance of card, inaccessibility of card line, twice debit of amount, confusion among staffs, double swipe as major problems. They even complained that card did not work while making payment.

It was found that most of the debit card users used the card because of its ease of use and usefulness, security, and their trust on them.They usea card as asubstitute of cash/check, and responded that they were satisfied using the card. The non-users of debit payment,on the other hand, responded that the transaction fee was as major factor for not using debit card.However, their level of interest along with their intention to use the service in near future was high.

\subsection{The Hypothesis Testing}

It has explained that there is statistical mean difference in the payment behaviour across nationalities and income; and there is statistical relationship between the debit-payment behaviour and perceived ease of use and usefulness. It also examined that there is significant relationship between frequency of purchase and frequency of debit card use at Bhat-Bhateni(i.e. the higher the frequency of purchase from Bhat-Bhateni, the higher is the probability of debit card usage for payments at the store). Moreover, the testing verified that there is mean difference statistically in the non-debit payment behaviour across the age group, i.e. older people are less likely to not to use debit cards at point-of-sales than the younger ones.

The analysis predicted that the correlation exists between independent variables of debit-payment behavior i.e. Perceived ease of use and usefulness and security; Perceived ease of use and usefulness and trust; Perceived ease of use and 
usefulness and external influence; security and trust; security and incentives; security and external influence etc. The table-2 and table-3explained the actual outcome of the collected information.

Table. 2: Multiple regression analysis for consumers' debit payment behaviour

\begin{tabular}{|l|l|l|l|l|l|}
\hline $\mathbf{R}$ & $\begin{array}{l}\mathbf{R} \\
\text { Square }\end{array}$ & $\begin{array}{l}\text { Adjusted R } \\
\text { Square }\end{array}$ & $\begin{array}{l}\text { Std. Error of the } \\
\text { Estimate }\end{array}$ & $\begin{array}{l}\text { F- } \\
\text { value }\end{array}$ & $\begin{array}{l}\text { p- } \\
\text { value }\end{array}$ \\
\hline $\begin{array}{l}0.74 \\
7\end{array}$ & 0.559 & 0.536 & 0.43196 & 24.812 & 0.000 \\
\hline
\end{tabular}

Table. 3: Coefficient of variables for consumers' debit payment behavior

\begin{tabular}{|c|c|c|c|c|c|c|}
\hline \multirow[t]{2}{*}{ Model 1} & \multicolumn{2}{|c|}{$\begin{array}{l}\text { Un-standardized } \\
\text { Coefficients }\end{array}$} & \multirow{2}{*}{$\begin{array}{l}\text { Standardized } \\
\text { Coefficients } \\
\text { Beta }\end{array}$} & \multirow[t]{2}{*}{ t-value } & \multirow[t]{2}{*}{ p-value } & \multirow{2}{*}{$\begin{array}{l}\text { Co- } \\
\text { linearity } \\
\text { Statistics } \\
\text { (VIF) }\end{array}$} \\
\hline & Beta & Std. Error & & & & \\
\hline (Constant) & 0.598 & 0.277 & - & 2.163 & 0.033 & \\
\hline PEU & 0.691 & 0.101 & 0.702 & 6.828 & 0.000 & 2.346 \\
\hline Security & -0.048 & 0.094 & -0.053 & -0.513 & 0.609 & 2.373 \\
\hline Trust & 0.094 & 0.075 & 0.123 & 1.247 & 0.216 & 2.155 \\
\hline Incentives & 0.01 & 0.045 & 0.017 & 0.222 & 0.825 & 1.281 \\
\hline $\begin{array}{l}\text { External } \\
\text { Influence }\end{array}$ & -0.017 & 0.048 & -0.027 & -0.348 & 0.728 & 1.292 \\
\hline
\end{tabular}

Multiple regression analysis reveals that the model- 1 on consumers' debit payment behaviour is highly significant in which the five independent variables explain $55.9 \%$ of the variance in the dependent variable. In contrary to this,model-2 based on non-debit payment behaviour is not significant since the variables only explain $3.6 \%$ variance in the dependent variable. However, among the independent variables of non-debit payment behaviour, unawareness and distrust, unawareness and unfamiliarity, transaction fee and distrust, transaction fee and unfamiliarity, distrust and unfamiliarity are positively and significantly correlated with each other.

\section{Concluding Remarks}

The research can be regarded as one of the primary studies to analyze debit payment behaviour of consumers at any departmental store in Nepal. The outcome of the survey research shows that there is a shift in consumer preferences in using debit card at point-of-sales, but cash is still highly preferred by the consumers for making purchases. The results show that significant attribute affecting debit card usages are: nationalities and income. By understanding these factors, the concerned 
authorities like bankers, retailers, government agencies and others have an opportunity to increase payments from debit cards by targeting the right group and expanding to new markets and thus provide value added services.

The study revealed that the customers are satisfied with debit use, and the nondebit users are interested to use the card for purchases and intend to use the card in near future. The awareness level and familiarity with such payment system is also high but marketers and bank authorities are not paying much attention to increase such debit use. Moreover, the research highlights the problems faced by consumers while using the card for payment.

The study also concludes that the results obtained from the present survey can help the concerned authorities in Nepal in providing them insight into the consumers' behaviour in terms of debit card payment.

This study has conducted a survey among limited respondents in Kathmandu Valley. Therefore, the readers can take this research as preliminary study for conducting broader consumer related survey with nationally representative samples. Future studies are suggested to extend the survey around other places of the country that include broad categories of respondents like regulators, service providers and consumers which will help to identify the significant factors that impact consumers' debit payment behaviour.

\section{REFERENCES}

Adeoti, O.O., Osotimehin, K.O and Olajide O.T (2013).Impact of Demographic and Socio-Economic Characteristics on the use of Debit Cards in Nigeria. Global Journal of Economics and Finance, 2(1), 12-19.

Bhatta, K. P. (2010). Customer Behaviour and Preferences: A Survey Report. Banking Journal, 1 (1), 63-74.

Blackwell, R. D., Miniard, P. W., \& Engel, J. F. (2007). Consumer Behavior(10th ed.). Haryana: Thomson.

Borzekowski, R., Kiser, E. K., \& Ahmed, S. (2006). Consumer's Use of Debit Cards: Patterns, Preferences and Price Response. Journal of Money, Credit and Banking, 40 (1), 149-172.

Cooper, D. R., \& Schindler, P. S. (2007).Business Research Methods (10th ed.). Tata McGraw-Hill.

Foster, K., Meijer, E., Schuh, S., \& Zabek, M. A. (2011).The 2009 Survey of Consumer Payment Choice.Boston: Federal Reserve Bank of Boston. 
Javeline Strategy and Research. (2012).Javelin Research: Cash Is No Longer King.San Franciso, CA: Javelin Strategy \& Research.

Kothari, C. R. (2004). Reseach Methodology: Methods and Techniques(2nd ed.). New Delhi: New Age Publications.

Kotler, P. (2000).Marketing Management(10th ed.). New Jersey: Prentice-Hall.

Kurtz, D. L., \& Boone, L. E. (2007). Principles of Marketing(12th ed.). Delhi: Thomson South Western.

Noknoi, C., Ngowsiri, S., \& Boripunt, W. (2009). Have debit cards changed Thai consumer shopping behavior? International Journal of Marketing Studies, 1 (2), 151-157.

Zikmund, W. G. (2007).Business Research Methods (7th ed.). Delhi: Thomson South Western. 